\title{
Article \\ Biochemical and Biophysical Characterization of Recombinant
Human 3-Phosphoglycerate Dehydrogenase
}

\author{
Giulia Murtas ${ }^{1, *(1)}$, Giorgia Letizia Marcone ${ }^{1}\left(\mathbb{D}\right.$, Alessio Peracchi $^{2}$, Erika Zangelmi ${ }^{2}\left(\mathbb{D}\right.$ and Loredano Pollegioni $^{1}$ \\ 1 Department of Biotechnology and Life Sciences, University of Insubria, via J.H. Dunant 3, 21100 Varese, Italy; \\ letiziamarcone@alice.it (G.L.M.); loredano.pollegioni@uninsubria.it (L.P.) \\ 2 Department of Chemistry, Life Sciences and Environmental Sustainability, University of Parma, \\ 43124 Parma, Italy; alessio.peracchi@unipr.it (A.P.); erika.zangelmi@unipr.it (E.Z.) \\ * Correspondence: g.murtas@uninsubria.it
}

Citation: Murtas, G.; Marcone, G.L.; Peracchi, A.; Zangelmi, E.; Pollegioni,

L. Biochemical and Biophysical Characterization of Recombinant Human 3-Phosphoglycerate Dehydrogenase. Int. J. Mol. Sci. 2021, 22, 4231. https://doi.org/10.3390/ ijms22084231

Academic Editor: Vito Turk

Received: 25 February 2021

Accepted: 14 April 2021

Published: 19 April 2021

Publisher's Note: MDPI stays neutral with regard to jurisdictional claims in published maps and institutional affiliations.

Copyright: (c) 2021 by the authors. Licensee MDPI, Basel, Switzerland. This article is an open access article distributed under the terms and conditions of the Creative Commons Attribution (CC BY) license (https:/ / creativecommons.org/licenses/by/ $4.0 /)$.

\begin{abstract}
The human enzyme D-3-phosphoglycerate dehydrogenase (hPHGDH) catalyzes the reversible dehydrogenation of 3-phosphoglycerate (3PG) into 3-phosphohydroxypyruvate (PHP) using the $\mathrm{NAD}^{+} / \mathrm{NADH}$ redox cofactor, the first step in the phosphorylated pathway producing L-serine. We focused on the full-length enzyme that was produced in fairly large amounts in E. coli cells; the effect of $\mathrm{pH}$, temperature and ligands on hPHGDH activity was studied. The forward reaction was investigated on 3PG and alternative carboxylic acids by employing two coupled assays, both removing the product PHP; 3PG was by far the best substrate in the forward direction. Both PHP and $\alpha$-ketoglutarate were efficiently reduced by hPHGDH and NADH in the reverse direction, indicating substrate competition under physiological conditions. Notably, neither PHP nor L-serine inhibited $\mathrm{hPHGDH}$, nor did glycine and D-serine, the coagonists of NMDA receptors related to L-serine metabolism. The investigation of NADH and phosphate binding highlights the presence in solution of different conformations and/or oligomeric states of the enzyme. Elucidating the biochemical properties of hPHGDH will enable the identification of novel approaches to modulate L-serine levels and thus to reduce cancer progression and treat neurological disorders.
\end{abstract}

Keywords: L-serine; D-serine; NAD; biochemical properties; metabolism; NMDA receptor; neurotransmission; cancer progression; phosphorylated pathway; serine deficiency

\section{Introduction}

D-3-phosphoglycerate dehydrogenase (PHGDH, EC 1.1.1.95) catalyzes the transformation of D-3-phosphoglycerate (3PG) into 3-phosphohydroxypyruvate (PHP) using $\mathrm{NAD}^{+} / \mathrm{NADH}$ as a cofactor (Figure 1). This is the first and the rate-determining step in the "phosphorylated pathway", also termed the serine synthesis pathway [1]. The equilibrium of the reaction lies far in the direction of 3PG: at equilibrium, less than 5\% of the substrate/product is in the form of PHP [2]; the reaction proceeds in the direction of serine synthesis because the product is continuously utilized in the subsequent steps. This provides a mechanism that preserves 3PG for later steps in glycolysis by using it in the phosphorylated pathway only when serine is required.

Serine supports a number of anabolic processes, including protein, lipid and nucleic acid synthesis. In humans, L-serine is available from different sources, i.e., from intestinal absorption of dietary proteins, degradation of proteins and phospholipids and conversion of glycine via serine hydroxymethyltransferase. The phosphorylated pathway represents the primary route of de novo L-serine synthesis, especially in the central nervous system [3], considering the low permeability of the amino acid at the blood-brain barrier [4]. This pathway involves three enzymes which are coordinately expressed in many tissues: phosphoserine aminotransferase (PSAT), phosphoserine phosphatase (PSP) and PHGDH. The key role of PHGDH in L-serine synthesis has been demonstrated through the generation of knock-out mouse models [3]. L-Serine is the precursor of D-serine, the coagonist of 
the N-methyl-D-aspartate receptors (NMDAR). NMDARs are critically involved in brain development and plasticity, cognitive functions and cellular excitotoxicity, and NMDAR dysfunction is often responsible for cognitive deficits that develop during normal aging and in neurological disorders [5,6]. D-serine is synthesized by serine racemase from Lserine and degraded by serine racemase and D-amino acid oxidase $[7,8]$ : the control of D-serine synthesis by acting on human serine racemase or D-amino acid oxidase is a difficult task since both enzymes show a $\mathrm{K}_{\mathrm{m}}$ for the $\mathrm{D}$-amino acid that is 20-fold higher than physiological concentration $[7,9,10]$. For a comprehensive recent review on L-serine and neurotransmission, see [11].

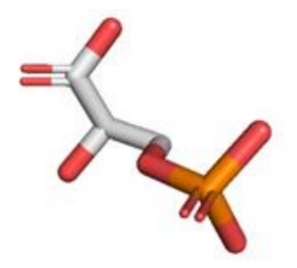

D-3-phosphoglycerate (3PG)

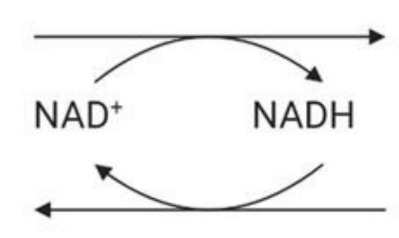

\section{3-phosphohydroxypyruvate (PHP)}

Figure 1. First reaction of the phosphorylated pathway: D-3-phosphoglycerate dehydrogenase catalyzes the $\mathrm{NAD}^{+}$-dependent conversion of D-3-phosphoglycerate into 3-phosphohydroxypyruvate.

The overexpression of the gene encoding PHGDH has been identified in human cancers, particularly in breast cancers and melanomas [12-15], and PHGDH inhibition was reported to reduce proliferation. PHGDH is involved in nucleotide synthesis by supporting central one-carbon metabolism [16]. Furthermore, in the last decade, several mutations have been correlated to PHGDH deficiency [17-19]. Five homozygous missense mutations have been identified in several individuals with congenital microcephaly, psychomotor retardation and variable presence of seizures [17,20-22].

PHGDH has been characterized in various organisms, from bacteria to mammals; for a review, see [23]. It is a cytosolic enzyme which exists in at least three different basic structural forms, named type I, II and III. Both Mycobacterium tuberculosis and human PHGDH (hPHGDH, made up of 533 amino acids for a mass of $56.8 \mathrm{kDa}$ ) belong to the structurally most complex type I (they share a $38 \%$ sequence identity). Actually, all types of PHGDH contain two common domains: the substrate-binding domain and the cofactorbinding domain; the type I members contain two additional regulatory domains at the $\mathrm{C}$ terminus, the ACT (aspartate kinase-chorismate mutase-tyrA prephenate dehydrogenase) and ASB (allosteric substrate-binding) domains. The $\mathrm{NAD}^{+}$and the substrate-binding domains appear to be conserved among species, while sequence conservation is low or insignificant for the other two domains. In selected species, the ACT domain has been reported to function as a binding site for serine to provide feedback inhibition, although this regulatory mechanism was not evident for hPHGDH [24]. The structure of a truncated version of hPHGDH, named sPHGDH (residues 3-314), which contains the substratebinding domain and the cofactor-binding domain only, was solved [24].

In recent years, various studies have been conducted on the full-length and the truncated versions of hPHGDH, such as the binding and kinetics of the physiological substrate 3PG and alternative substrates [24-26] and the identification of inhibitors [27,28]. Here, we performed an in-depth biochemical characterization of recombinant full-length hPHGDH. This represents an essential step in understanding the physiological production of L-serine through the phosphorylated pathway (and, in turn, of D-serine) and in identifying the alterations due to hPHGDH mutations that are related to pathological states. 


\section{Results}

\subsection{Expression of Recombinant $h P H G D H$}

His-tagged full-length hPHGDH was expressed in BL21(DE3) E. coli cells carrying the pETM-hPHGDH expression plasmid. Following the addition of isopropyl- $\beta$ D-thiogalactoside (IPTG), the maximal activity value in the crude extract was observed after $20 \mathrm{~h}$ at $20{ }^{\circ} \mathrm{C}$, corresponding to 0.12 units $/ \mathrm{mg}$ of total proteins. The recombinant hPHGDH was purified from the crude extract by chromatography on a HiTrap Chelating column and was nearly homogeneous after this single step: SDS-PAGE analysis showed a single band of the expected size ( $\sim 0 \mathrm{kDa}$ vs. a theoretical value of $59.776 \mathrm{kDa}$, Figure S1). After dialysis, the preparation had a specific activity of $1.3 \mathrm{U} / \mathrm{mg}$ of protein. From $1 \mathrm{~L}$ of culture, $125 \mathrm{U}(96 \mathrm{mg})$ of purified enzyme was obtained with an $83 \%$ recovery yield (Table S1). While a number of studies have focused on the truncated sPHGDH form (see Section 1), three papers reported on the expression of full-length hPHGDH in E. coli cells as the His-tagged form, although no details on the production levels were reported [24,27,29].

\subsection{Kinetic Properties and Substrate Specificity}

The reaction of recombinant hPHGDH on 3PG (forward direction) was assayed following the fluorescence signal related to the redox state of the nicotinamide cofactor and removing the PHP product using PSAT (the following enzyme in the phosphorylated pathway) or $200 \mathrm{mM}$ hydrazine. The enzymatic activity of recombinant hPHGDH was similar in $50 \mathrm{mM}$ HEPES at pH 7.5, $25 \mathrm{mM}$ HEPES at pH 7.0, and $50 \mathrm{mM}$ TrisHCl at $\mathrm{pH} 8.5$ buffer (not shown), while it was strongly affected by phosphate (see below). When assayed using a multicomponent buffer, the recombinant hPHGDH showed the highest activity at $\mathrm{pH} \sim 8$ and apparent $\mathrm{pK}_{\mathrm{a}}$ values at 2.8, 7.4 and 10.2; see Figure S2A. Notably, the enzyme was stable after $30 \mathrm{~min}$ of incubation at 4,25 and $37^{\circ} \mathrm{C}$ and at $\mathrm{pH}$ values $\geq 4.0$ and $\leq 9.0$, while at longer incubation times, the activity was largely maintained in the $\mathrm{pH}$ range $4-5$ only (see Figure S2B for the time course following the incubation at $37^{\circ} \mathrm{C}$ ). The highest residual activity was maintained at $4{ }^{\circ} \mathrm{C}$, independently of the $\mathrm{pH}$ (not shown).

When the hPHGDH activity was measured in the physiological direction by the PSAT-coupled assay at $0.12 \mathrm{mM} \mathrm{NAD}^{+}$and increasing $3 \mathrm{PG}$ concentrations (Figure S3A), a $K_{m}$ value of $0.26 \mathrm{mM}$ for $3 P G$ and a $k_{\text {cat }}$ of $1.5 \mathrm{~s}^{-1}$ were determined using a classical Michaelis-Menten equation: no evidence of allosteric behavior at low substrate concentration was apparent, and no substrate inhibition was observed at high 3PG concentration (up to $15 \mathrm{mM}$ ). Notably, very close kinetic parameters were determined using hydrazine to eliminate the reaction product instead of PSAT (Figure S3A and Table 1). Using a fixed and saturating amount of $3 \mathrm{PG}$ (i.e., $2.5 \mathrm{mM}$ ) and increasing $\mathrm{NAD}^{+}$concentrations, a $\mathrm{k}_{\text {cat }}$ of $2.2 \mathrm{~s}^{-1}$ was determined (Figure S3A). This latter value is higher than the one determined at $120 \mu \mathrm{M} \mathrm{NAD}^{+}$; this apparent discrepancy is due to the use of a subsaturating $\mathrm{NAD}^{+}$concentration in the previous reaction (the corresponding $\mathrm{K}_{\mathrm{m}}$ value is $0.15 \mathrm{mM}$ ). Accordingly, the forward reactions were assayed at $1.5 \mathrm{mM} \mathrm{NAD}^{+}$(Figure S3): the corresponding values are reported in Table 1.

To gain insights into the substrate preferences of hPHGDH, compounds similar to 3PG, such as D-3-hydroxybutyrate, D-lactate, D-tartrate and D-malate, were tested. All these compounds were oxidized by hPHGDH but with $\mathrm{K}_{\mathrm{m}}$ values higher than the one for the physiological substrate 3PG (see Figure S3D-F and Table 1) and with a lower $k_{\text {cat }}$ value for $\mathrm{D}$-tartrate and $\mathrm{D}$-malate (this pointing to differences in the microscopic rate constants limiting the turnover number). We conclude that these compounds are not likely to compete with 3PG for dehydrogenation by hPHGDH under physiological conditions. 
Table 1. Apparent kinetic parameters of recombinant $\mathrm{hPHGDH}$ at $37^{\circ} \mathrm{C}$ and $\mathrm{pH}$ 7.0. Values are per monomer.

\begin{tabular}{|c|c|c|c|c|c|c|}
\hline Substrate & Formula & $\begin{array}{l}\mathbf{k}_{\text {cat }} \\
\left(s^{-1}\right)\end{array}$ & $\begin{array}{c}\mathrm{K}_{\mathrm{m}} \\
(\mathrm{mM})\end{array}$ & $\begin{array}{c}\mathbf{k}_{\mathrm{cat}} / \mathbf{K}_{\mathrm{m}} \\
\left(\mathrm{mM}^{-1} \mathbf{s}^{-1}\right)\end{array}$ & Assay $^{a}$ & Conditions $^{b}$ \\
\hline \multicolumn{7}{|c|}{ Forward reaction: } \\
\hline \multirow{2}{*}{ 3-Phosphoglycerate (3PG) } & & $1.48 \pm 0.37$ & $0.255 \pm 0.059$ & 5.80 & 1,2 & $1 \mathrm{a}$ \\
\hline & & $2.97 \pm 0.09$ & $0.360 \pm 0.061$ & 8.25 & 2 & $1 b$ \\
\hline D-Lactate & & $5.41 \pm 0.15$ & $151 \pm 9$ & 0.036 & 2 & $1 b$ \\
\hline D-3-Hydroxybutyrate & & $2.53 \pm 0.27$ & $41 \pm 19$ & 0.061 & 2 & $1 b$ \\
\hline D-Tartrate & & $0.41 \pm 0.03$ & $5.55 \pm 2.73$ & 0.074 & 2 & $1 b$ \\
\hline D-Malate & & $0.44 \pm 0.01$ & $4.48 \pm 0.87$ & 0.098 & 2 & $1 b$ \\
\hline $\mathrm{NAD}^{+}$ & & $2.23 \pm 0.26$ & $0.148 \pm 0.021$ & 15.1 & 1,2 & 2 \\
\hline
\end{tabular}

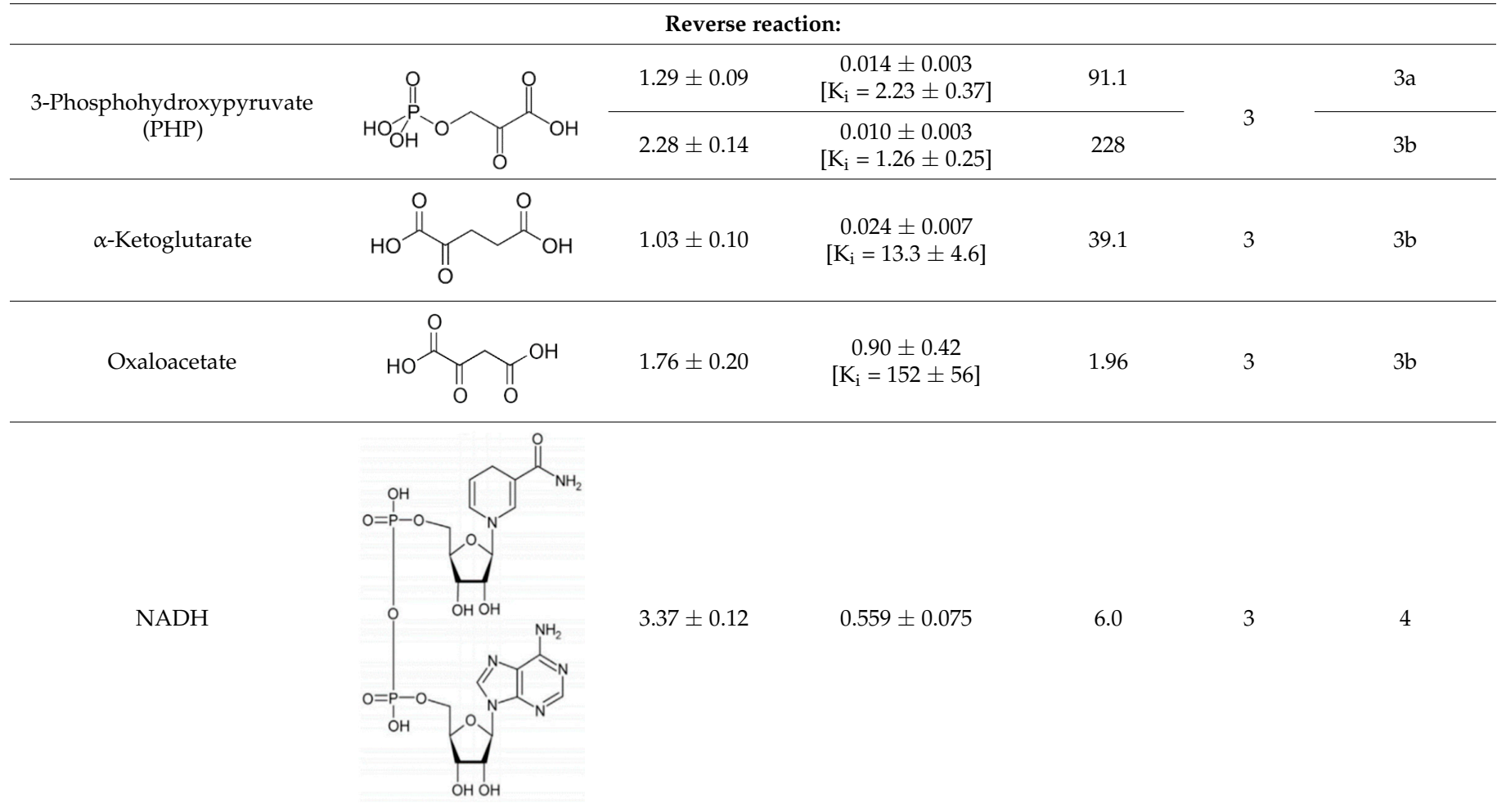

a The forward reaction was assayed using a coupled assay with PSAT (1) or by reacting the product PHP with 200 mM hydrazine (2). The reverse reaction was assayed following the redox state of the cofactor as fluorescence change at $450 \mathrm{~nm}(3) .{ }^{b}$ The assay was performed at $37^{\circ} \mathrm{C}$ in $25 \mathrm{mM}$ Hepes pH 7.0 and (1) a: $120 \mu \mathrm{M} \mathrm{NAD}^{+}$, b: $1.5 \mathrm{mM} \mathrm{NAD}^{+}$; (2) $2.5 \mathrm{mM} 3 \mathrm{PG}$; (3) a: $150 \mu \mathrm{M} \mathrm{NADH}, \mathrm{b}: 5 \mathrm{mM}$ NADH; (4) $0.5 \mathrm{mM}$ PHP. 
When the hPHGDH reaction was assayed in the opposite direction at $150 \mu \mathrm{M}$ NADH and increasing PHP concentrations, an apparent $\mathrm{k}_{\mathrm{cat}}$ of $1.3 \mathrm{~s}^{-1}$ and a $\mathrm{K}_{\mathrm{m}}$ of $14 \mu \mathrm{M}$ for PHP were determined; a substrate inhibition effect was apparent at PHP concentrations higher than $0.3 \mathrm{mM}\left(\mathrm{K}_{\mathrm{i}}=2.23 \mathrm{mM}\right.$, Figure $\mathrm{S} 4$ and Table 1), confirming the result reported by [26]. Using a fixed and saturating amount of PHP $(0.5 \mathrm{mM})$, the recombinant enzyme displayed an apparent $\mathrm{k}_{\text {cat }}$ of $3.4 \mathrm{~s}^{-1}$ and a $\mathrm{K}_{\mathrm{m}}$ for NADH of $0.56 \mathrm{mM}$ (Figure S4B); accordingly, the reverse reactions were assayed using $5 \mathrm{mM} \mathrm{NADH}$ (Table 1). The reverse reaction was also assayed on $\alpha$-ketoglutarate and oxaloacetate (Figure S4); for the former substrate, the kinetic parameters resembled those determined for PHP with a substrate inhibition effect at concentrations higher than $1 \mathrm{mM}\left(\mathrm{K}_{\mathrm{i}} \sim 13 \mathrm{mM}\right)$, while for oxaloacetate, a higher apparent $\mathrm{K}_{\mathrm{m}}$ value was determined (see Table 1). Interestingly, from a kinetic point of view, $\alpha$-ketoglutarate could compete with PHP for NADH reduction by hPHGDH in vivo, generating the oncometabolite D-2-hydroxyglutarate.

$\alpha$-Ketoglutarate can be generated by the reaction of PSAT, the next enzyme in the phosphorylated pathway, using L-glutamate as an amino donor, as reported by [25]. As the equilibrium of the reaction catalyzed by hPHGDH is largely favored in the direction of 3PG formation (reverse reaction), only a small amount of NADH is generated under standard conditions in the presence of $2.4 \mathrm{mM} 3 \mathrm{PG}$ and $0.12 \mathrm{mM} \mathrm{NAD}^{+}$. We observed that NADH production is faster when hPHGDH is coupled with PSAT in the presence of $2.5 \mathrm{mM}$ 3PG, $0.12 \mathrm{mM} \mathrm{NAD}^{+}$and $30 \mathrm{mM}$ L-glutamate, which, instead, is reversed when adding $10 \mathrm{mM} \alpha$-ketoglutarate and omitting PSAT. The observation that a specific reoxidation step of NADH is not required in the presence of PHGDH, PSAT and L-glutamate needs further investigation.

\subsection{Cofactor Binding}

The absorbance spectrum of hPHGDH shows a maximum intensity at $280 \mathrm{~nm}$, and the protein fluorescence spectrum, following excitation at $280 \mathrm{~nm}$, shows a peak at $330 \mathrm{~nm}$. Interestingly, the fluorescence intensity is quenched by adding NADH and, most significantly, $\mathrm{NAD}^{+}$(Figure 2A), indicating that cofactor binding induced a conformational change.

The far-UV CD spectrum of hPHGDH, with minima at 208 and $222 \mathrm{~nm}$ (Figure 2B), is indicative of a large amount of $\alpha$-helices (approx. $62 \%$ vs. $5 \%$ of $\beta$-sheets, as calculated using the DichroWeb software, Selcon3 method) [30]. The cofactor slightly altered the secondary structure content: in the presence of $\mathrm{NAD}^{+}$or $\mathrm{NADH}$, the percentage of $\alpha$-helices decreased to $55 \%$ and $52 \%$, respectively, while the value corresponding to $\beta$-sheets content increased slightly (9\% and 11\%, respectively) (Figure 2B). Concerning the near-UV CD spectrum, the addition of both redox forms of the nicotinamide cofactor significantly altered the 250 to $290 \mathrm{~nm}$ region, corresponding to the signal for aromatic residues (Figure 2C), pointing to a protein conformational change associated with cofactor binding. In detail, a different contribution of the signal due to tyrosine residues (at $\sim 280 \mathrm{~nm}$ ) was observed following $\mathrm{NAD}^{+}$binding (increase) vs. NADH binding (decrease); in both cases, an alteration of the tryptophan region of influence (at $\sim 290 \mathrm{~nm}$ ) was also apparent.

The binding constant for the nicotinamide cofactor was determined by titrating the enzyme with increasing amounts of $\mathrm{NAD}^{+}$or NADH and monitoring holoenzyme reconstitution, following the fluorescence intensity at $330 \mathrm{~nm}$ (using excitation wavelengths at both 280 and $298 \mathrm{~nm}$ ). The binding of $\mathrm{NAD}^{+}$to hPHGDH was a monophasic process, with a $K_{d}$ value of $130 \mu \mathrm{M}$ (Figure 3A,B), while the quenching in protein fluorescence intensity vs. NADH concentration was biphasic (Figure 3C,D); a first saturation was apparent up to $\sim 3 \mu \mathrm{M} \mathrm{NADH}$, corresponding to $\sim 35 \%$ of the change in fluorescence intensity, and a second saturation was evident up to $\sim 300 \mu \mathrm{M}$ NADH. The corresponding $\mathrm{K}_{\mathrm{d}}$ values are 0.49 and $168 \mu \mathrm{M}$, respectively (Table 2). The binding of NADH to hPHGDH was also investigated in the presence of an amount of $3 \mathrm{PG}$ corresponding to its $\mathrm{K}_{\mathrm{m}}$ value $(0.25 \mathrm{mM})$ or to a saturating amount $(2.5 \mathrm{mM})$ : the change in fluorescence intensity was again biphasic, but the amplitude of the first phase decreased to $20 \%$ and $12 \%$ of the total change, respectively. $\mathrm{K}_{\mathrm{d}}$ values for the first phase were 1.2 and $1.7 \mu \mathrm{M}$ at 0.25 and $2.5 \mathrm{mM}$ 3PG, respectively, 
while those for the second phase $(\sim 130 \mu \mathrm{M})$ were similar to the value determined for the free enzyme (Table 2). These results suggest an equilibrium between two hPHGDH forms differing in NADH affinity; the presence of a ligand in the active site favors the species at lower affinity.
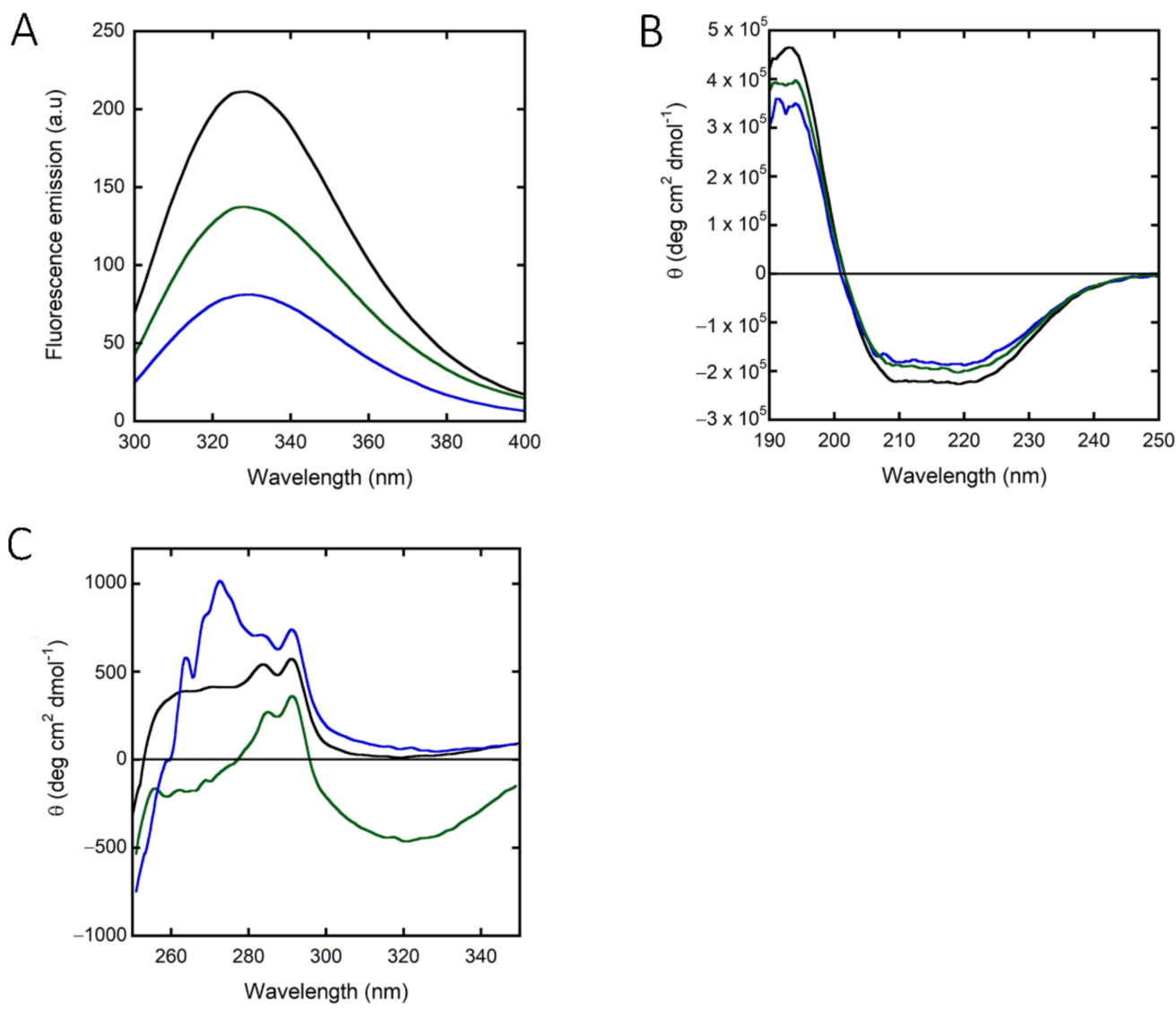

Figure 2. Spectral properties of recombinant hPHGDH alone (black) and in the presence of $0.12 \mathrm{mM}$ $\mathrm{NAD}^{+}$(blue) or $0.10 \mathrm{mM}$ NADH (green). Comparison of: (A) fluorescence emission spectra $(0.1 \mathrm{mg} / \mathrm{mL}$, excitation at $280 \mathrm{~nm})$; (B) far-UV CD spectra $(0.1 \mathrm{mg} / \mathrm{mL})$; (C) near-UV CD spectra $(0.4 \mathrm{mg} / \mathrm{mL})$.

Table 2. Binding of nicotinamide cofactors and selected inhibitors to hPHGDH.

\begin{tabular}{|c|c|c|}
\hline Ligand & $K_{d}(\mu M)$ & Assay \\
\hline $\mathrm{NAD}^{+}$ & $130.3 \pm 8.3$ & Quenching of protein fluorescence (at $15^{\circ} \mathrm{C}$ ) \\
\hline $\begin{array}{c}\mathrm{NADH}^{\mathrm{a}} \\
\text { first phase (free) } \\
(+0.25 \mathrm{mM} \text { 3PG) } \\
\text { (+2.5 mM 3PG) } \\
\text { second phase (free) } \\
\text { (+0.25 mM 3PG) } \\
(+2.5 \mathrm{mM} 3 \mathrm{PG})\end{array}$ & $\begin{array}{c}0.49 \pm 0.03(35 \%) \\
1.20 \pm 0.02(20 \%) \\
1.71 \pm 0.07(12 \%) \\
169 \pm 27(65 \%) \\
129 \pm 23(80 \%) \\
134 \pm 9(88 \%)\end{array}$ & Quenching of protein fluorescence (at $15^{\circ} \mathrm{C}$ ) \\
\hline NCT-503 & $\begin{array}{c}24.0 \pm 5.0 \\
\mathrm{IC}_{50}=5.75 \pm 2.33 \\
\mathrm{~K}_{\mathrm{i}}=17.7\end{array}$ & $\begin{array}{l}\text { Quenching of protein fluorescence }\left(\text { at } 15^{\circ} \mathrm{C}\right) \\
\text { Inhibition of activity at } 2.4 \mathrm{mM} 3 \mathrm{PG} \text { and } 0.12 \mathrm{mM} \mathrm{NAD}{ }^{+}\left(\text {at } 37^{\circ} \mathrm{C}\right) \\
\text { Inhibition of activity at different } 3 \mathrm{PG} \text { concentrations and } 0.12 \mathrm{mM} \\
\mathrm{NAD}^{+}\left(\text {at } 37^{\circ} \mathrm{C}\right)\end{array}$ \\
\hline CBR-5884 & $\begin{array}{c}\mathrm{IC}_{50}=1.02 \pm 0.37 \\
\mathrm{~K}_{\mathrm{i}}=5.7\end{array}$ & $\begin{array}{l}\text { Inhibition of activity at } 2.4 \mathrm{mM} 3 \mathrm{PG} \text { and } 0.12 \mathrm{mM} \mathrm{NAD}{ }^{+}\left(\text {at } 37^{\circ} \mathrm{C}\right) \\
\text { Inhibition of activity at different } 3 \mathrm{PG} \text { concentrations and } 0.12 \mathrm{mM} \\
\qquad \mathrm{NAD}^{+}\left(\text {at } 37^{\circ} \mathrm{C}\right)\end{array}$ \\
\hline
\end{tabular}

Reported values are mean \pm SD for three measurements. ${ }^{a}$ In parenthesis is reported the amplitude of protein fluorescence quenching associated with each phase. 
A

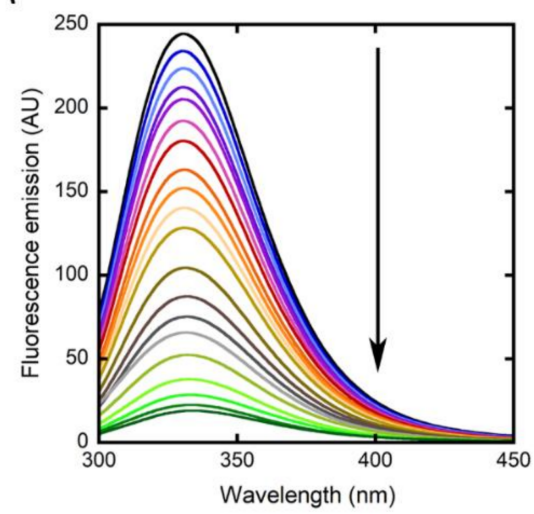

C

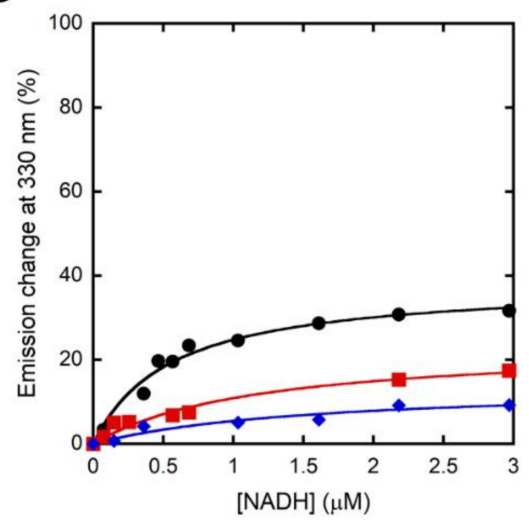

B

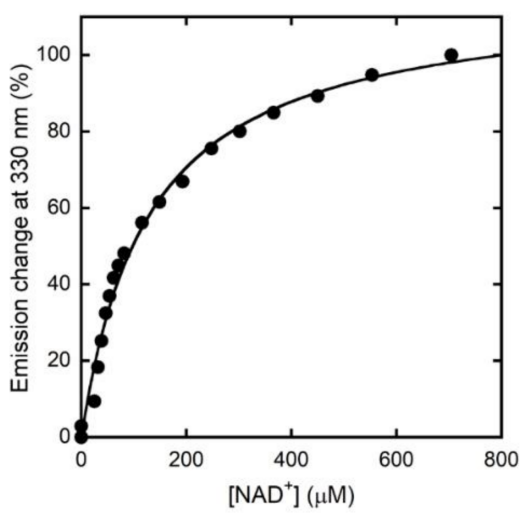

D

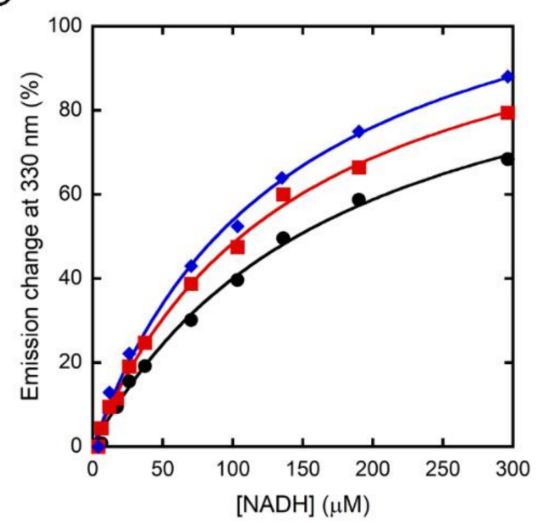

Figure 3. Effect of cofactor binding on the protein fluorescence emission spectrum of hPHGDH $(1 \mu \mathrm{M}): \mathrm{NAD}^{+}(\mathbf{A}, \mathbf{B})$ and NADH $(\mathbf{C}, \mathbf{D})$. Arrow in panel A indicates the spectral changes at increasing $\mathrm{NAD}^{+}$concentration. In panels $\mathrm{C}$ and $\mathrm{D}$, the binding of NADH was evaluated in the absence (black) and presence of 0.25 (red) or $2.5 \mathrm{mM}$ (blue) 3PG. Panel C shows the fit of the values, expressed as a percentage of the total fluorescence change, corresponding to the first saturation phase of the protein fluorescence change (up to $3 \mu \mathrm{M}$ of cofactor concentration). Panel D shows the best fit for the second phase of saturation. Measurements were performed at $15{ }^{\circ} \mathrm{C}$ and repeated three times for each condition.

The effect of temperature on protein unfolding was evaluated by monitoring spectral signals related to the protein tertiary structure. Following the changes in protein fluorescence intensity at $330 \mathrm{~nm}$ (due to both Trp and Tyr residues) [31], a melting temperature $\left(\mathrm{T}_{\mathrm{m}}\right)$ of $48.4{ }^{\circ} \mathrm{C}$ was determined for the enzyme alone, a figure that increased to 52.4 and $55.7^{\circ} \mathrm{C}$ for the enzyme incubated with $120 \mu \mathrm{M} \mathrm{NAD}^{+}$or $100 \mu \mathrm{M}$ NADH (Table 3). Slightly different values were determined by following the circular dichroism signal at $280 \mathrm{~nm}$ (characteristic of Tyr residues) [32]; $\mathrm{T}_{\mathrm{m}}$ was $47.5^{\circ} \mathrm{C}$ for the protein alone and 48.2 and $51.0^{\circ} \mathrm{C}$ for the protein with $120 \mu \mathrm{M} \mathrm{NAD}^{+}$or $100 \mu \mathrm{M} \mathrm{NADH}$, respectively. This result suggests that cofactor binding, especially NADH, alters hPHGDH conformation, driving the acquisition of a more stable structure.

Table 3. Melting temperature values determined for recombinant hPHGDH with or without the cofactors.

\begin{tabular}{ccc}
\hline & \multicolumn{2}{c}{$\mathbf{T}_{\mathbf{m}}\left({ }^{\circ} \mathbf{C}\right)$} \\
\cline { 2 - 3 } & $\mathbf{C D} \mathbf{( 2 2 0 ~ \mathbf { ~ m } )}$ & Fluorescence (330 $\mathbf{~ n m})$ \\
\hline hPHGDH & $47.2 \pm 0.5$ & $48.4 \pm 2.1$ \\
$+120 \mu \mathrm{M} \mathrm{NAD}^{+}$ & $48.2 \pm 1.7$ & $52.4 \pm 0.4$ \\
$+100 \mu \mathrm{M} \mathrm{NADH}$ & $51.0 \pm 0.3$ & $55.7 \pm 0.1$ \\
\hline
\end{tabular}




\subsection{Ligand Binding}

hPHGDH activity was affected by the presence of mono- or divalent ions $\left(\mathrm{K}^{+}, \mathrm{Na}^{+}\right.$, $\mathrm{Ca}^{2+}$ and $\mathrm{Mg}^{2+}$ ); the strongest effect was a $40 \%$ decrease at $10 \mathrm{mM} \mathrm{KCl}$ (Figure S5). The latter influence might be of physiological relevance, since the $\mathrm{KCl}$ level in cytosol is $\sim 160 \mathrm{mM}$. The activity of hPHGDH on $2.4 \mathrm{mM}$ 3PG was not affected by the product PHP (up to $50 \mathrm{mM}$ final concentration) and only marginally affected by the presence of D-serine, Lserine and glycine; the most evident effect was a $\sim 25 \%$ decrease at $250 \mathrm{mM}$ D-serine (a nonphysiological concentration; see Figure S6).

In recent years, several investigations have focused on identifying and characterizing new inhibitors of hPHGDH for their potential use as drugs to treat cancer progression $[27,28,33]$. Here, we selected two of these molecules and evaluated their effect on full-length hPHGDH. NCT-503 inhibited enzymatic activity, yielding an $\mathrm{IC}_{50}$ of $5.8 \mu \mathrm{M}$ (Figure $4 \mathrm{~A}$ and Table 2). The kinetics of hPHGDH on 3PG were thus investigated at increasing NCT-503 concentration; as shown by the plots reported in Figure $4 \mathrm{C}, \mathrm{E}$, the inhibitor was able to alter both the apparent maximal rate and the $\mathrm{K}_{\mathrm{m}}$ value for 3PG. Thus, NCT-503 acts as a noncompetitive inhibitor; a $\mathrm{K}_{\mathrm{i}}$ of $23.4 \mu \mathrm{M}$ was estimated (see Figure $4 \mathrm{G}$ ). Even the CBR-5884 compound affected hPHGDH activity; the $\mathrm{IC}_{50}$ was $\sim 1.0 \mu \mathrm{M}$ (Figure $4 \mathrm{~B}$ ). A noncompetitive inhibition was also apparent for CBR-5884 from the plots reported in Figure $4 \mathrm{D}, \mathrm{F} ; \mathrm{a} \mathrm{K}_{\mathrm{i}} \sim 5.7 \mu \mathrm{M}$ was estimated (see Figure $4 \mathrm{H}$ and Table 2).

We then investigated the ability of the two inhibitors to alter hPHGDH conformation by following the quenching of protein fluorescence. A decrease in protein fluorescence was apparent at increasing concentrations of NCT-503, yielding a $K_{d}$ value of $24 \mu \mathrm{M}$ (similar to the $\mathrm{K}_{\mathrm{i}}$ value; Table 2). The same analysis was not feasible for CBR-5884 due to the strong fluorescence observed at $>150 \mu \mathrm{M}$ concentration.

\subsection{Oligomeric State and Phosphate Effect}

On gel permeation chromatography using a Superdex 200 Increase column, the recombinant hPHGDH eluted as a major peak corresponding to approx. $240 \mathrm{kDa}$ (Figure S7A), indicating that it behaved as a tetramer. A second minor peak at $\sim 480 \mathrm{kDa}$ was apparent at increasing concentrations of potassium phosphate, as confirmed by Western blot analysis, indicating that an octameric oligomer representing $9-20 \%$ of the total protein was present. This seems to be a specific effect due to phosphates as the peak corresponding to the octameric form was absent in $20 \mathrm{mM}$ phosphate buffer and was not generated when the ionic strength was increased by adding $\mathrm{NaCl}$ (Figure S7A). Notably, a similar effect was apparent for M. tuberculosis PHGDH [34].

The enzymatic activity is strongly affected by phosphate ions; $30 \%$ of the activity was lost at $1 \mathrm{mM}$ potassium phosphate (corresponding to the cellular level), and it was fully abrogated at $400 \mathrm{mM}$ phosphate (Figure S7B, left). The time course of the activity assay showed that the inhibition occurred quickly after adding $250 \mathrm{mM}$ potassium phosphate (see Figure S7B, right). Interestingly, the reverse reaction was similarly affected by the potassium phosphate concentration (compare blue and red bars in Figure S7B). When $\mathrm{KCl}$ or $\mathrm{NaCl}$ was used instead of potassium phosphate, $30 \%$ of the initial activity was also lost at $\geq 10$ and $>20 \mathrm{mM}$ salt concentration, respectively, and the activity was never fully abolished (Figure S8). Indeed, a similar behavior was apparent at increasing concentrations of sodium tartrate, a compound used to generate crystals of truncated sPHGDH [24]. 
A

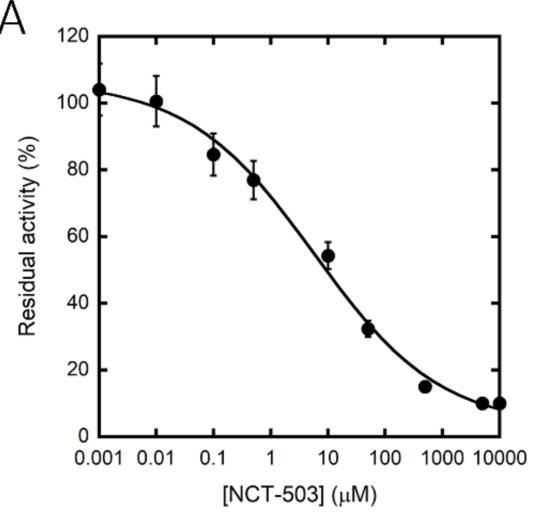

C

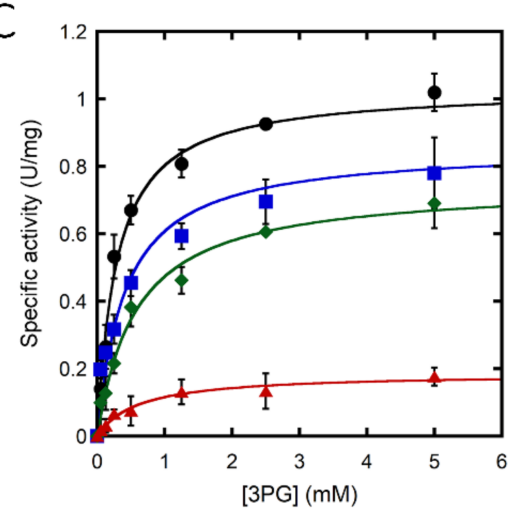

E
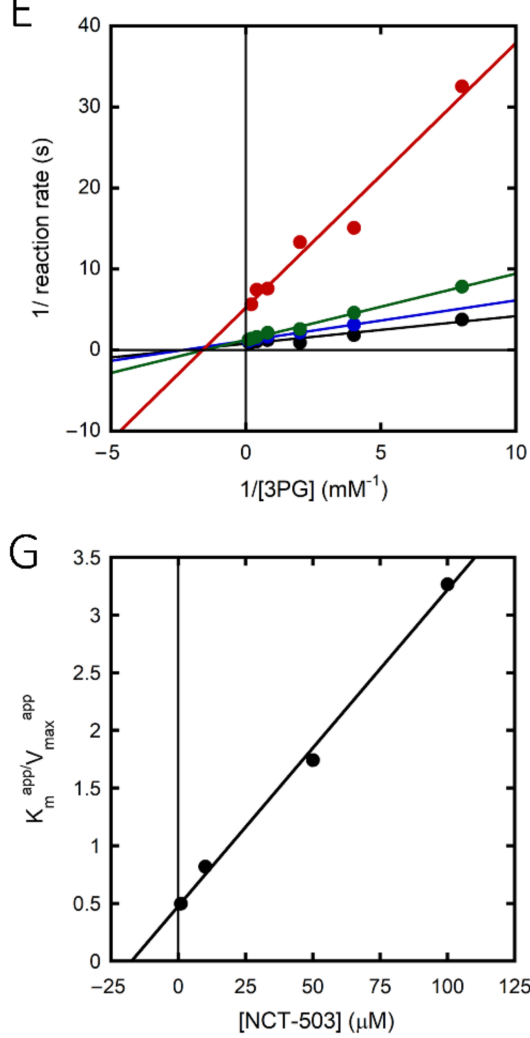

B
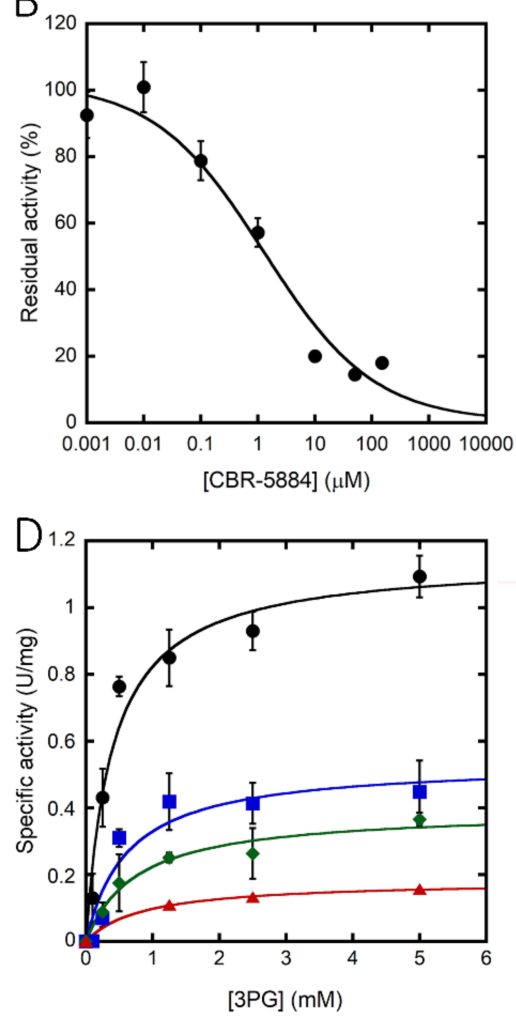

F
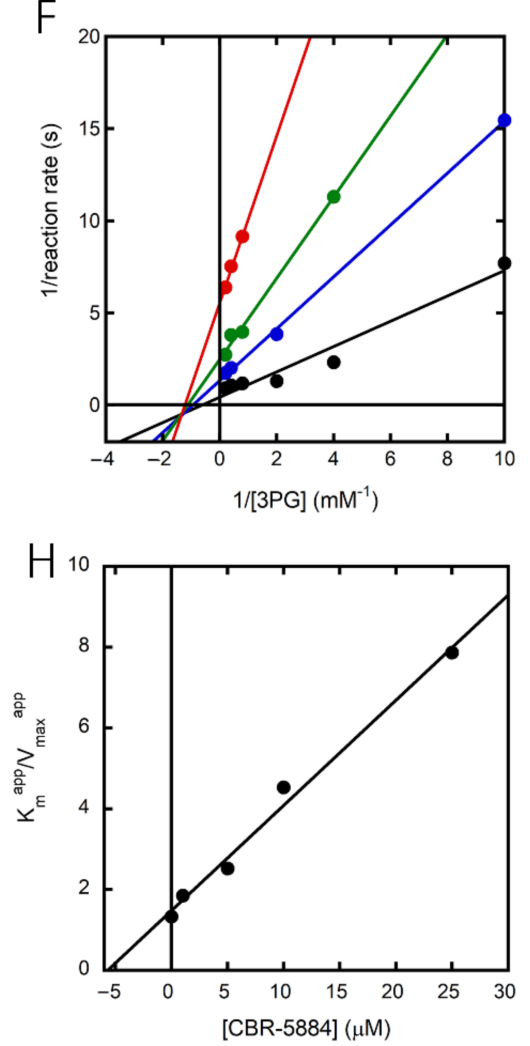

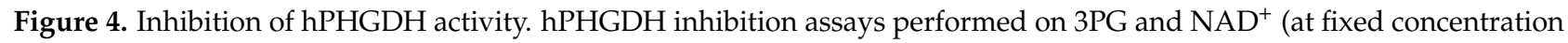
of 2.4 and $0.12 \mathrm{mM}$, respectively) in the presence of different amounts of NCT-503 (A) or CBR-5884 (B). (C,D) Kinetics of hPHGDH on 3PG in the presence of increasing concentrations of NCT-503 (at 0, 1, 10 and $100 \mu \mathrm{M}$; lines from top to bottom) or CBR-5884 (at 0, 0.1, 1 and $10 \mu \mathrm{M}$; lines from top to bottom). Data are the average of three determinations and error bars represent mean $\pm S D$. (E,F) Double reciprocal plot of data as in panels $C$ and $D . K_{i}$ value for both the inhibitors was estimated by fitting the apparent $K_{m} / V_{\max }$ values calculated at different inhibitor concentrations $(\mathrm{G}, \mathbf{H})$. 


\subsection{Conformational Changes}

The binding of NADH and the effect of salt concentration (see above) as well as the ability of tartrate to generate crystals of truncated sPHGDH suggest that different conformational states exist in solution of this complex enzyme. We used limited proteolysis to evaluate the presence of such hPHGDH species based on the assumption that specific regions of the protein are differently susceptible to trypsinolysis in the free and complexed forms. Following the addition of $5 \%(w / w)$ trypsin, the full-length $56 \mathrm{kDa}$ form of hPHGDH was quickly converted (in $120 \mathrm{~min}$ ) into a $\sim 40 \mathrm{kDa}$ band, with the transient presence of a $\sim 47 \mathrm{kDa}$ species and additional products at 28, 25, 15 and $10 \mathrm{kDa}$ (Figure S9A). The band at $\sim 40 \mathrm{kDa}$ should be expected to arise after deleting the C-terminal portion, thus lacking the ASB and ACT domains (residues 1-370). Based on a model of hPHGDH structure, we predict Arg370 as a susceptible site to trypsinolysis since it is located in a linker region connecting the substrate-binding domain and the cofactor-binding domain with the two additional regulatory domains ACT and ASB. Proteolysis of the full-length enzyme was hampered in the presence of $250 \mathrm{mM}$ potassium phosphate or $500 \mathrm{mM}$ sodium tartrate (Figure S9B,C) and, to a lesser extent, by $0.1 \mathrm{mM}$ NCT-503 (Figure S9D). On the other hand, the generation of the $40 \mathrm{kDa}$ species was favored by adding the cofactor $\mathrm{NAD}^{+}$, the substrate 3PG or both (Figure S9E-G).

\section{Discussion}

In this paper, we report on the recombinant expression of full-length hPHGDH in E. coli cells. By optimizing the growth conditions, $\sim 100 \mathrm{mg}$ of pure enzyme per liter of fermentation broth was obtained. Recombinant hPHGDH was easily purified by a single chromatographic step, and this allowed us to biochemically characterize the enzyme.

The full-length hPHGDH showed the highest activity at $\mathrm{pH} 8$, similarly to the E. coli counterpart, a behavior that distinguishes it from $M$. tuberculosis PHGDH, which displayed optimal activity at pH 6.5 [23]. The hPHGDH activity was not affected by the buffer composition (with the only exception of phosphate; see below), and the enzyme showed an appreciable thermostability for a mesophilic protein $\left(\mathrm{T}_{\mathrm{m}} \sim 48^{\circ} \mathrm{C}\right)$. The binding of $\mathrm{NAD}^{+}$ to $\mathrm{hPHGDH}$ is a monophasic process, while the binding of NADH is biphasic; similar $\mathrm{K}_{\mathrm{d}}$ values were apparent for $\mathrm{NAD}^{+}$and for the main phase of NADH binding $(\sim 0.13 \mathrm{mM}$; Table 2), while the minor phase of NADH binding was characterized by a higher affinity. The amplitude of the minor phase decreased at increasing 3PG concentrations, pointing to the presence of two protein conformations in solution whose equilibrium is affected by the active-site ligand. Such conformations might be related to the asymmetrical tetramer made up of independent dimers used to explain the flip-flop reaction mechanism of E. coli PHGDH [35]. Notably, similar $K_{m}$ values were determined for the oxidized and reduced forms of the nicotinamide cofactor when the forward and reverse reactions were studied $\left(0.15 \mathrm{mM}\right.$ for $\mathrm{NAD}^{+}$vs. $0.56 \mathrm{mM}$ for NADH). Previous work on the truncated hPHGDH form has reported a lower $K_{d}$ value for NADH binding based on isothermal calorimetry analyses $(=0.2 \mu \mathrm{M}$, resembling the value for the first phase we observed; see Table 1) [24], while the value for $\mathrm{NAD}^{+}$binding corresponded to the value we determined for the fulllength enzyme; apart from the different protein and method used, no other explanation can be provided to justify such a difference. The cofactor binding affected the tertiary structure of hPHGDH and increased its thermostability (especially NADH; see Table 3), as previously reported [24].

hPHGDH catalyzed a reversible reaction (Figure 1); the reverse reaction starting from PHP was strongly favored. We investigated the forward reaction using two coupled assays and defined the experimental conditions ( $25 \mathrm{mM}$ Hepes buffer at $\mathrm{pH} 7$ and $\left.37^{\circ} \mathrm{C}\right)$. Notably, the kinetic parameters determined using the coupled assay with PSAT overlapped with those determined with hydrazine (Figure S3A), suggesting the latter is a simple and suitable method to assay the hPHGDH forward reaction.

$\mathrm{hPHGDH}$ is a promiscuous enzyme, active on various carboxylic acids containing 3 to 5 carbon atoms (Table 1). 3PG is the best substrate due to its low apparent $K_{m}(0.36 \mathrm{mM}$ at 
$1.5 \mathrm{mM} \mathrm{NAD}^{+}$); all the alternative substrates showed $\mathrm{K}_{\mathrm{m}}$ values of orders of magnitude higher, thus likely not affecting the reaction of hPHGDH on 3PG at the physiological level. The $K_{m}$ values previously reported for $\mathrm{hPHGDH}$ (i.e., 0.18, 0.26 and $0.48 \mathrm{mM}$ ) [24,25,35] are in good agreement with the value we determined. In any case, discrepancies are also apparent; in a previous work, the kinetics with 3PG showed a negative cooperativity (Hill coefficient $n=0.63-0.67$ ), and $\alpha$-ketoglutarate was not efficiently utilized to produce $\alpha$-hydroxyglutarate [35]. On the other hand, when a commercial preparation of hPHGDH was used [25], no cooperativity with 3PG was described (as well as in [24]), and similar $\mathrm{k}_{\text {cat }}$ values for 3PG and $\alpha$-ketoglutarate were determined, as in our analyses (Table 1).

Concerning the reverse reaction, an apparent $\mathrm{k}_{\text {cat }}$ value similar to that for the forward reaction was determined (Table 1), but, since the $\mathrm{K}_{\mathrm{m}}$ for PHP was $\sim 10 \mu \mathrm{M}$ (vs. a figure of 85 and $40 \mu \mathrm{M}$ for the $M$. tuberculosis and the E. coli enzymes) $[23,36]$, the kinetic efficiency $\mathrm{k}_{\mathrm{cat}} / \mathrm{K}_{\mathrm{m}}$ ratio was 20-fold higher than for the forward reaction on 3PG. Such a value for hPHGDH is lower than those reported for the M. tuberculosis and the E. coli enzymes, corresponding to $5.6 \times 10^{6} \mathrm{M}^{-1} \mathrm{~s}^{-1}$ and $7 \times 10^{5} \mathrm{M}^{-1} \mathrm{~s}^{-1}$, respectively [23,36]. hPHGDH also efficiently uses $\alpha$-ketoglutarate as substrate, analogously to the enzyme from $E$. coli (showing a comparatively higher $\mathrm{K}_{\mathrm{m}}$ and lower kinetic efficiency, i.e., $0.5 \mathrm{mM}$ and $3 \times 10^{4} \mathrm{M}^{-1} \mathrm{~s}^{-1}$ ) and differently from the ones from $M$. tuberculosis and rat liver [23]. The observed reduction of $\alpha$-ketoglutarate by hPHGDH generating the oncometabolite D-2-hydroxyglutarate confirms a study based on commercial enzyme preparation [25], although the previous study reported a very slow reaction rate and a $\mathrm{K}_{\mathrm{m}}$ of $\sim 10 \mathrm{mM}$ for $\alpha$-ketoglutarate. Nevertheless, in both investigations, the $\mathrm{k}_{\text {cat }}$ values for $3 \mathrm{PG}$ and $\alpha$-ketoglutarate were very close (see Figure S2A,C in [25]), and the specific activity on 3PG of the commercial enzyme used in [25] was in good agreement with the value for our hPHGDH preparation $(\sim 1.3 \mathrm{U} / \mathrm{mg}$ protein). Indeed, we suggest that the use of $\alpha$ ketoglutarate (generated by PSAT from L-glutamate or by the cellular metabolism) by hPHGDH provides for a mechanism in which L-serine production could proceed without a net consumption of $\mathrm{NAD}^{+}$. Interestingly, for the reverse reaction on both $\mathrm{PHP}$ and $\alpha$-ketoglutarate, a substrate inhibition effect was apparent $\left(\mathrm{K}_{\mathrm{i}}\right.$ in the millimolar range), confirming previous results on human, M. tuberculosis and rat liver PHGDHs [26,37].

hPHGDH activity is partially affected by mono- and divalent ions (Figure S5) and not affected by relevant amino acids linked to the phosphorylated pathway, such as Dand L-serine and glycine (Figure S6). The absence of L-serine inhibition indicates that no feedback inhibition is active for hPHGDH, in contrast to that of the E. coli and the $M$. tuberculosis counterparts [35,37].

The binding of two known inhibitors was studied on the full-length enzyme; both NCT-503 and CBR-5884 compounds inhibited the forward reaction of hPHGDH by a noncompetitive inhibition mechanism and one- or two-digit micromolar dissociation and inhibition constants (Table 2). The results for CBR-5884 do not differ significantly from those determined using the truncated sPHGDH form [38].

hPHGDH in solution is a homotetramer of $\sim 240 \mathrm{kDa}$, like the enzymes from E. coli [39], rabbit liver [40] and chicken liver [41]. In the presence of phosphate ions, a second minor peak was generated corresponding to a molecular mass of $\sim 480 \mathrm{kDa}$, i.e., an octameric oligomer. Such an effect was not due to the ionic strength of the solution, as the minor peak was not generated at increasing $\mathrm{KCl}$ concentrations. The presence of phosphate strongly and quickly inhibited hPHGDH (Figure S7); 30\% of the activity was lost at $1 \mathrm{mM}$ phosphate, a physiological cellular concentration. A conformational change induced by phosphate was proposed for $M$. tuberculosis PHGDH, suggesting that it affects the interaction between the ACT and the ASB domains compared to the structure solved in the presence of $1 \mathrm{M}$ tartrate [34]. Awaiting the resolution of the 3D structure of free and complexed full-length hPHGDH, we used different techniques to highlight changes in protein conformation, such as spectral analyses (Figure 2), temperature-induced unfolding (Table 3) and limited proteolysis. The latter experiments suggest that the $\mathrm{C}$-terminal portion, harboring the allosteric ACT and ASB domains, can be easily cleaved by trypsin and that phosphate 
and tartrate protect hPHGDH from this cleavage (Figure S9). Indeed, $\mathrm{NAD}^{+}$and $3 \mathrm{PG}$ protect the $\sim 40 \mathrm{kDa}$ protein species from further proteolysis. Similarly to that observed at increasing phosphate concentrations, $\mathrm{NaCl}, \mathrm{KCl}$ and sodium tartrate also inhibited hPHGDH (Figure S8). Taken together, several lines of evidence suggest that different conformations and/or oligomeric states exist for hPHGDH.

The nonessential amino acid L-serine is critical for a plethora of metabolic pathways and physiological processes; thus, a deeper knowledge of its biosynthetic pathway is essential to shed light on related defects. hPHGDH is a complex enzyme made by four domains, possessing an oligomeric organization, catalyzing a reversible reaction and showing substrate and catalytic promiscuity; by investigating this enzyme, we can identify novel approaches to reduce cancer progression and to modulate neurotransmission in disorders due to L-serine deficiency and to NMDAR-altered functioning.

\section{Materials and Methods}

\subsection{Design, Synthesis and Cloning of hPHGDH Gene}

The synthetic gene encoding hPHGDH was designed by in silico back translation of the amino acid sequence reported in the data bank (GenBank accession number CAG33076.1). The codon usage was optimized for expression in E. coli. The gene was produced by Invitrogen ( $h$ PHGDH_pMA-T). The cDNA molecule was cloned into the pETM11 expression plasmid with $\mathrm{NcoI}$ and XhoI (Roche, Milan, Italy) restriction sites (pETM-hPHGDH plasmid). With this cloning strategy, a 6xHis-tag encoded by the plasmid was added at the $\mathrm{N}$-terminus of the protein that could eventually be eliminated by cleavage with TEV protease. The cloned regions were confirmed by sequencing (Euroclone, Milan, Italy).

\subsection{Expression and Purification of Recombinant $h P H G D H$ and $h P S A T$}

For hPHGDH overexpression in E. coli, BL21(DE3) cells (Invitrogen, Milan, Italy) transformed with the pETM-hPHGDH expression plasmid were aerobically grown at $37^{\circ} \mathrm{C}$ in Luria Bertani broth up to $\mathrm{OD}_{600 \mathrm{~nm}} \approx 0.6-0.8$. The growth was then stopped by incubation for $30 \mathrm{~min}$ on ice before adding $0.5 \mathrm{mM}$ IPTG to induce the expression of the enzyme. Growth was continued for another $20 \mathrm{~h}$ at $20^{\circ} \mathrm{C}$. Cells were harvested by centrifugation $\left(6000 \times g, 30 \mathrm{~min}, 4^{\circ} \mathrm{C}\right)$ and frozen. Pellets were resuspended in lysis buffer $(50 \mathrm{mM}$ potassium phosphate, $10 \mathrm{mM} \mathrm{MgCl} 2,200 \mathrm{mM} \mathrm{KCl}, 10 \%(v / v)$ glycerol, $1 \mu \mathrm{g} / \mathrm{mL}$ DNAse, $0.7 \mu \mathrm{g} / \mathrm{mL}$ pepstatin and $0.19 \mathrm{mg} / \mathrm{mL}$ PMSF) using $3.5 \mathrm{~mL} / \mathrm{g}$ cells; the cells were disrupted by sonication for 2-3 min. Cell debris was removed by centrifugation at $27,000 \times g$ for $1 \mathrm{~h}$ and the crude extract purified by chromatography on a HiTrap Chelating column (Invitrogen, Milan, Italy) loaded with $\mathrm{NiCl}_{2}$ and using the following solutions: starting buffer, $50 \mathrm{mM}$ sodium pyrophosphate, $\mathrm{pH} 7.5,300 \mathrm{mM} \mathrm{NaCl}$ and $2 \%(v / v)$ glycerol; elution buffer, $50 \mathrm{mM}$ sodium pyrophosphate, $\mathrm{pH} 7.5,0.5 \mathrm{M}$ imidazole and $2 \%(v / v)$ glycerol. The final enzyme preparations were stored at $-80{ }^{\circ} \mathrm{C}$ in $50 \mathrm{mM}$ sodium pyrophosphate, $\mathrm{pH} 7.5$, $10 \mathrm{mM} \mathrm{MgCl}_{2}, 25 \mathrm{mM} \mathrm{NaCl}, 2 \%(v / v)$ glycerol and $2.5 \mathrm{mM}$ 2-mercaptoethanol (added for long-term storage). The enzyme concentration was determined spectrophotometrically by using the theoretical extinction coefficient at $280 \mathrm{~nm}\left(40.45 \mathrm{mM}^{-1} \mathrm{~cm}^{-1}\right)$. PSAT was expressed in E. coli BL21-CodonPlus ${ }^{\circledR}$-RIL cells and purified as detailed elsewhere [42]. Briefly, bacteria were grown in M9-glucose medium containing $50 \mu \mathrm{g} / \mathrm{mL}$ kanamycin and $34 \mu \mathrm{g} / \mathrm{mL}$ chloramphenicol at $37^{\circ} \mathrm{C}$ and transferred, after induction with $1 \mathrm{mM}$ IPTG, at $4^{\circ} \mathrm{C}$ and grown for 3 days. The protein was purified by IMAC on a Talon cobalt affinity resin using an AKTA apparatus. The final protein preparation was stored in $25 \mathrm{mM}$ Tris, $300 \mathrm{mM} \mathrm{NaCl}, 4 \mu \mathrm{M}$ PLP and $1 \mathrm{mM}$ TCEP, $\mathrm{pH} 8.0$, at $-80^{\circ} \mathrm{C}$. The final PSAT preparation had a specific activity of about $10 \mathrm{U} / \mathrm{mg}$ protein.

\subsection{Activity Assay and Kinetic Measurements}

$\mathrm{hPHGDH}$ activity in the physiological direction and the apparent kinetic parameters on 3PG were determined by monitoring NADH fluorescence (recording the emission at $450 \mathrm{~nm}$ following excitation at $360 \mathrm{~nm}$ ) over time at $37^{\circ} \mathrm{C}$ in 96 -well plates with TECAN 
Infinite 200 Pro (Männedorf, Switzerland), a procedure partially modified from [28]. PSAT was added to drive the reaction and to avoid product inhibition of hPHGDH. One unit corresponds to the amount of enzyme that converts $1 \mu \mathrm{mol}$ of $3 \mathrm{PG}$ in one minute at $37^{\circ} \mathrm{C}$. The assays were performed using $0.04 \mu \mathrm{g}$ hPHGDH (0.001 U) in $25 \mathrm{mM}$ Hepes, $\mathrm{pH}$ 7.0, on $2.5 \mathrm{mM}$ 3PG and in the presence of $120 \mu \mathrm{M}$ or $1.5 \mathrm{mM} \mathrm{NAD}^{+}, 30 \mathrm{mM}$ glutamate and $0.032 \mathrm{U}$ of PSAT.

The apparent kinetic parameters on 3PG and $\mathrm{NAD}^{+}$were determined using both the PSAT-coupled assay (in the presence of 2.5 , and 0.120 or $1.5 \mathrm{mM}$ of the substrate or cofactor, respectively) and the procedure from [25], in which $200 \mathrm{mM}$ hydrazine was added instead of PSAT to drive the reaction forward. The latter assay was used to determine the apparent kinetic parameters on alternative substrates. $K_{m}$ and $V_{\max }$ values were calculated according to a Michaelis-Menten equation using the initial velocity values determined at increasing substrate concentrations, i.e., up to $15 \mathrm{mM}$ 3PG, $10 \mathrm{mM} \mathrm{NAD}^{+}, 500 \mathrm{mM}$ D-malic acid, $500 \mathrm{mM}$ 3-hydroxybutyric acid, $500 \mathrm{mM}$ D-tartaric acid and $300 \mathrm{mM}$ D-lactic acid. The kinetics on 3PG were determined with both assays. hPHGDH activity in the reverse direction was also assayed monitoring the fluorescence change at $450 \mathrm{~nm}$, using increasing substrate concentration and $150 \mu \mathrm{M}$ or $5 \mathrm{mM} \mathrm{NADH}$. Plots of activity vs. substrate concentration were fit to the general Michaelis-Menten equation modified to account for a substrate inhibition effect yielding complete inhibition and no cooperativity [26]: $\mathrm{v}=\mathrm{V}_{\max }[\mathrm{S}] /\left[1+\left(\mathrm{K}_{\mathrm{m}}+[\mathrm{S}]+\left([\mathrm{S}]^{2} / \mathrm{K}_{\mathrm{i}}\right)\right]\right.$. The $\mathrm{k}_{\text {cat }}$ values were calculated per monomer (of $59.8 \mathrm{kDa}$ ). The concentration of (intact) PHP and $\alpha$-ketoglutarate solutions was confirmed by measuring the level of NADH conversion using an excess of hPHGDH and bovine L-glutamate dehydrogenase, respectively.

The effects of $\mathrm{KCl}, \mathrm{NaCl}, \mathrm{MgCl}_{2}$ and $\mathrm{CaCl}_{2}$ and of $\mathrm{pH}$ and temperature on enzyme activity and stability were investigated using the hydrazine assay. The activity was assayed after incubation at 4,25 or $37^{\circ} \mathrm{C}$ of $1.4 \mathrm{mg} / \mathrm{mL}$ hPHGDH at different $\mathrm{pH}$ values in a multicomponent buffer $\left(15 \mathrm{mM}\right.$ Tris- $\mathrm{HCl}, 15 \mathrm{mM} \mathrm{Na}_{2} \mathrm{CO}_{3}, 15 \mathrm{mM} \mathrm{H}_{3} \mathrm{PO}_{4}, 100 \mathrm{mM} \mathrm{KCl}$ and $1 \%(v / v)$ glycerol) for up to $1400 \mathrm{~min}$ [43]. The dependence of activity on $\mathrm{pH}$ was fitted using an equation for three $\mathrm{pK}_{\mathrm{a}}$ values, according to [44], providing apparent values unrelated to microscopic ones.

The hydrazine assay was used to evaluate the effect of phosphate and $\mathrm{KCl}$, serine synthesis metabolites (D-Ser, L-Ser and Gly) and inhibitors (NCT-503 and CBR-5884 dissolved in DMSO; the maximal solubility of the CBR-5884 is $\leq 1 \mathrm{mM}$ ) on hPHGDH activity, and thus to determine $\mathrm{IC}_{50}$ and $\mathrm{K}_{\mathrm{i}}$ values and the mechanism of inhibition.

$\mathrm{hPHGDH}$ activity in the reverse direction was determined by monitoring the decrease in NADH fluorescence over time at $37^{\circ} \mathrm{C}$. The assays were performed using $0.02 \mathrm{U}(0.6 \mu \mathrm{g})$ of enzyme in $25 \mathrm{mM}$ Hepes, $\mathrm{pH}$ 7.0, on different amounts of PHP and in the presence of $0.15 \mathrm{mM}$ NADH or on $0.5 \mathrm{mM}$ PHP and different amounts of the cofactor.

\subsection{Determination of Oligomerization State}

Size-exclusion chromatography was carried out using a Superdex 200 Increase column on an AKTA system. The column was equilibrated with increasing concentrations (20, 100,250 and $500 \mathrm{mM}$ ) of potassium phosphate, $\mathrm{pH} 7.0 ; 0.15 \mathrm{M} \mathrm{NaCl}$ was added at low phosphate concentrations (20 and $100 \mathrm{mM}$ ). The presence of hPHGDH in the eluted peaks was confirmed by SDS-PAGE and Western blot analyses by using a specific anti-His antibody (diluted 1:200, Santa Cruz Biotechnology Inc., Dallas, TX, USA).

\subsection{Spectral Measurements}

Circular dichroism (CD) spectra were recorded using a Jasco J-815 spectropolarimeter

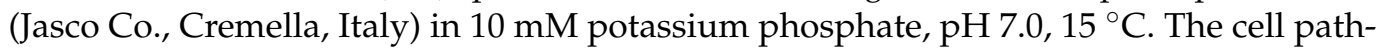
length was $0.1 \mathrm{~cm}$ for measurements in the 200 to $250 \mathrm{~nm}$ region $(0.1 \mathrm{mg}$ protein $/ \mathrm{mL})$ and $1 \mathrm{~cm}$ for measurements in the 250 to $350 \mathrm{~nm}$ range $(0.5 \mathrm{mg}$ protein $/ \mathrm{mL})$ [32].

Protein fluorescence spectra were measured at $0.06-0.1 \mathrm{mg} / \mathrm{mL}$ protein concentration in $10 \mathrm{mM}$ potassium phosphate, $\mathrm{pH} 7.0,15^{\circ} \mathrm{C}$; spectra were recorded using a Jasco FP-750 
instrument and were corrected for the buffer contribution. Protein fluorescence spectra were recorded between 300 and $450 \mathrm{~nm}$, with excitation at 280 and $298 \mathrm{~nm}$.

The ligand dissociation constants $\left(\mathrm{K}_{\mathrm{d}}\right)$ were estimated by titrating $1 \mu \mathrm{M}$ enzyme with increasing amounts of $\mathrm{NAD}^{+}, \mathrm{NADH}, \mathrm{NCT}-503$ or CBR-5884 and following the protein fluorescence quenching at $330 \mathrm{~nm}$. All recorded spectra were subtracted for the contribution of the ligand (added to the buffer only) and were corrected for dilution at every addition. The $\mathrm{K}_{\mathrm{d}}$ values for NADH to the hPHGDH moiety were determined in the presence and in the absence of 3PG $(0.25$ or $2.5 \mathrm{mM})$. In all cases, $\mathrm{K}_{\mathrm{d}}$ values were determined by fitting the data to a hyperbolic function. Temperature-ramp experiments were performed in $10 \mathrm{mM}$ potassium phosphate, $\mathrm{pH}$ 7.0. For this, a software-driven, Peltier-equipped fluorimeter was used to measure the protein fluorescence change at $330 \mathrm{~nm}$ or a CD spectropolarimeter to follow the $\mathrm{CD}$ signal at $280 \mathrm{~nm}$ in order to reproduce a temperature gradient $\left(0.5^{\circ} \mathrm{C} / \mathrm{min}\right)$ [31].

\subsection{Limited Proteolysis}

hPHGDH at $0.4 \mathrm{mg} / \mathrm{mL}$ was incubated at $25{ }^{\circ} \mathrm{C}$ in $50 \mathrm{mM}$ Hepes $\mathrm{pH} 7.5,100 \mathrm{mM}$ $\mathrm{NaCl}, 10 \%(v / v)$ glycerol, $1 \mathrm{mM}$ EDTA and $5 \mathrm{mM}$ 2-mercaptoethanol in the presence of $5 \%$ $(w / w)$ trypsin (Roche, Basel, Switzerland). The cofactor NAD $\mathrm{N}^{+}$and the substrate 3PG, alone and together (0.12 and $2.4 \mathrm{mM}$, respectively), potassium phosphate $(250 \mathrm{mM}), \mathrm{D}, \mathrm{L}$-tartaric acid $(500 \mathrm{mM})$ and the inhibitor NCT-503 $(0.1 \mathrm{mM})$ were added to the incubation mixture. At different times $(0,30,60,120$ and $240 \mathrm{~min}), 8 \mu \mathrm{g}$ of protein was diluted in SDS-sample buffer, heated at $95^{\circ} \mathrm{C}$ for $5 \mathrm{~min}$ and analyzed by SDS-PAGE.

Supplementary Materials: The following materials are available online at https:/ / www.mdpi.com/ article/10.3390/ijms22084231/s1, Figure S1: Purification of hPHGDH from E. coli crude extract; Figure S2: Effect of pH on activity and stability of hPHGDH; Figure S3: Kinetics of hPHGDH in the forward direction on different substrates; Figure S4: Kinetics of hPHGDH in the reverse direction on different substrates; Figure S5: Effect of monovalent and divalent ions on hPHGDH activity at $2.4 \mathrm{mM} 3 \mathrm{PG}$ and $0.12 \mathrm{mM}$ NAD+; Figure S6: D-serine, L-serine and glycine only marginally affect the activity of hPHGDH; Figure S7: Effect of phosphate ions on hPHGDH properties; Figure S8: Effect of concentration of different salts on hPHGDH activity; Figure S9: Limited proteolysis of hPHGDH evaluated by SDS-PAGE; Table S1: Purification of recombinant hPHGDH.

Author Contributions: Conceptualization, G.M. and L.P.; methodology, G.M. and G.L.M.; validation, G.M. and G.L.M.; investigation, G.M. and G.L.M.; resources, A.P. and E.Z.; data curation, G.M., G.L.M. and L.P.; writing_-original draft preparation, G.M. and G.L.M.; writing—review and editing, G.M., L.P., A.P. and E.Z.; visualization, G.M.; supervision, L.P.; funding acquisition, L.P. All authors have read and agreed to the published version of the manuscript.

Funding: This research was funded by a grant from Ministero Università e Ricerca Scientifica PRIN 2017 (Grant 2017H4J3AS) to L.P.

Data Availability Statement: Data are contained within the article or supplementary material. The data presented in this study are available on request from the corresponding author.

Conflicts of Interest: The authors declare no conflict of interest.

\section{References}

1. Murtas, G.; Marcone, G.L.; Sacchi, S.; Pollegioni, L. L-serine synthesis via the phosphorylated pathway in humans. Cell. Mol. Life Sci. 2020, 77, 5131-5148. [CrossRef] [PubMed]

2. Grant, G.A. Contrasting catalytic and allosteric mechanisms for phosphoglycerate dehydrogenases. Arch. Biochem. Biophys. 2012, 519, 175-185. [CrossRef] [PubMed]

3. Yang, J.H.; Wada, A.; Yoshida, K.; Miyoshi, Y.; Sayano, T.; Esaki, K.; Kinoshita, M.O.; Tomonaga, S.; Azuma, N.; Watanabe, M.; et al. Brain-specific PHGDH deletion reveals a pivotal role for L-serine biosynthesis in controlling the level of D-serine, an $\mathrm{N}$-methyl-D-aspartate receptor co-agonist, in adult brain. J. Biol. Chem. 2010, 285, 41380-41390. [CrossRef] [PubMed]

4. Furuya, S.; Tabata, T.; Mitoma, J.; Yamada, K.; Yamasaki, M.; Makino, A.; Yamamoto, T.; Watanabe, M.; Kano, M.; Hirabayashi, Y. L-serine and glycine serve as major astroglia-derived trophic factors for cerebellar Purkinje neurons. Proc. Natl. Acad. Sci. USA 2000, 97, 11528-11533. [CrossRef] 
5. Ivanov, A.D.; Mothet, J.P. The plastic D-serine signaling pathway: Sliding from neurons to glia and vice-versa. Neurosci. Lett. 2019, 689, 21-25. [CrossRef]

6. Ploux, E.; Freret, T.; Billard, J.M. D-Serine in physiological and pathological brain aging. Biochim. Biophys. Acta Proteins Proteom. 2021, 1869, 140542. [CrossRef]

7. Pollegioni, L.; Sacchi, S. Metabolism of the neuromodulator D-serine. Cell. Mol. Life Sci. 2010, 67, 2387-2404. [CrossRef]

8. Pollegioni, L.; Sacchi, S.; Murtas, G. Human D-amino acid oxidase: Structure, function, and regulation. Front. Mol. Biosci. 2018, 5, 107. [CrossRef]

9. Beato, C.; Pecchini, C.; Cocconcelli, C.; Campanini, B.; Marchetti, M.; Pieroni, M.; Mozzarelli, A.; Costantino, G. Cyclopropane derivatives as potential human serine racemase inhibitors, unveiling novel insights into a difficult target. J. Enzyme Inhib. Med. Chem. 2016, 31, 645-652. [CrossRef]

10. Raboni, S.; Marchetti, M.; Faggiano, S.; Campanini, B.; Bruno, S.; Marchesani, F.; Margiotta, M.; Mozzarelli, A. The energy landscape of human serine racemase. Front. Mol. Biosci. 2019, 5, 112. [CrossRef]

11. Maugard, M.; Vigneron, P.A.; Bolaños, J.P.; Bonvento, G. L-Serine links metabolism with neurotransmission. Prog. Neurobiol. 2021, 197, 101896. [CrossRef]

12. Possemato, R.; Marks, K.M.; Shaul, Y.D.; Pacold, M.E.; Kim, D.; Birsoy, K.; Sethumadhavan, S.; Woo, H.K.; Jang, H.G.; Jha, A.K.; et al. Functional genomics reveal that the serine synthesis pathway is essential in breast cancer. Nature 2011, 476, 346-350. [CrossRef]

13. Pollari, S.; Käkönen, S.M.; Edgren, H.; Wolf, M.; Kohonen, P.; Sara, H.; Guise, T.; Nees, M.; Kallioniemi, O. Enhanced serine production by bone metastatic breast cancer cells stimulates osteoclastogenesis. Breast Cancer Res. Treat. 2011, 125, 421-430. [CrossRef]

14. Mullarky, E.; Mattaini, K.R.; Heiden, M.G.V.; Cantley, L.C.; Locasale, J.W. PHGDH amplification and altered glucose metabolism in human melanoma. Pigment. Cell Melanoma Res. 2011, 24, 1112-1115. [CrossRef]

15. Amelio, I.; Cutruzzolá, F.; Antonov, A.; Agostini, M.; Melino, G. Serine and glycine metabolism in cancer. Trends Biochem. Sci. 2014, 39, 191-198. [CrossRef]

16. Reid, M.A.; Allen, A.E.; Liu, S.; Liberti, M.V.; Liu, P.; Liu, X.; Dai, Z.; Gao, X.; Wang, Q.; Liu, Y.; et al. Serine synthesis through PHGDH coordinates nucleotide levels by maintaining central carbon metabolism. Nat. Commun. 2018, 9, 5442. [CrossRef]

17. Tabatabaie, L.; de Koning, T.J.; Geboers, A.J.; van den Berg, I.E.; Berger, R.; Klomp, L.W. Novel mutations in 3-phosphoglycerate dehydrogenase (PHGDH) are distributed throughout the protein and result in altered enzyme kinetics. Hum. Mutat. 2009, 30, 749-756. [CrossRef]

18. Benke, P.J.; Hidalgo, R.J.; Braffman, B.H.; Jans, J.; Gassen, K.L.I.V.; Sunbul, R.; El-Hattab, A.W. Infantile serine biosynthesis defect due to phosphoglycerate dehydrogenase deficiency: Variability in phenotype and treatment response, novel mutations, and diagnostic challenges. J. Child Neurol. 2017, 32, 543-549. [CrossRef]

19. Ni, C.; Cheng, R.H.; Zhang, J.; Liang, J.Y.; Wei, R.Q.; Li, M.; Yao, Z.R. Novel and recurrent PHGDH and PSAT1 mutations in Chinese patients with Neu-Laxova syndrome. Eur. J. Dermatol. 2019, 29, 641-646. [CrossRef]

20. Klomp, L.W.; de Koning, T.J.; Malingré, H.E.; van Beurden, E.A.; Brink, M.; Opdam, F.L.; Duran, M.; Jaeken, J.; Pineda, M.; Van Maldergem, L.; et al. Molecular characterization of 3-phosphoglycerate dehydrogenase deficiency-A neurometabolic disorder associated with reduced L-serine biosynthesis. Am. J. Hum. Genet. 2000, 67, 1389-1399. [CrossRef]

21. Pind, S.; Slominski, E.; Mauthe, J.; Pearlman, K.; Swoboda, K.J.; Wilkins, J.A.; Sauder, P.; Natowicz, M.R. V490M, a common mutation in 3-phosphoglycerate dehydrogenase deficiency, causes enzyme deficiency by decreasing the yield of mature enzyme. J. Biol. Chem. 2002, 277, 7136-7143. [CrossRef]

22. Tabatabaie, L.; Klomp, L.W.; Rubio-Gozalbo, M.E.; Spaapen, L.J.; Haagen, A.A.; Dorland, L.; de Koning, T.J. Expanding the clinical spectrum of 3-phosphoglycerate dehydrogenase deficiency. J. Inherit. Metab. Dis. 2011, 34, 181-184. [CrossRef]

23. Grant, G.A. D-3-Phosphoglycerate dehydrogenase. Front. Mol. Biosci. 2018, 5, 110. [CrossRef]

24. Unterlass, J.E.; Wood, R.J.; Baslé, A.; Tucker, J.; Cano, C.; Noble, M.M.E.; Curtin, N.J. Structural insights into the enzymatic activity and potential substrate promiscuity of human 3-phosphoglycerate dehydrogenase (PHGDH). Oncotarget 2017, 8, 104478-104491. [CrossRef]

25. Fan, J.; Teng, X.; Liu, L.; Mattaini, K.R.; Looper, R.E.; Heiden, M.G.V.; Rabinowitz, J.D. Human phosphoglycerate dehydrogenase produces the oncometabolite D-2-hydroxyglutarate. ACS Chem. Biol. 2015, 10, 510-516. [CrossRef]

26. Xu, X.L.; Chen, S.; Salinas, N.D.; Tolia, N.H.; Grant, G.A. Comparison of type 1 D-3-phosphoglycerate dehydrogenases reveals unique regulation in pathogenic Mycobacteria. Arch. Biochem. Biophys. 2015, 570, 32-39. [CrossRef]

27. Pacold, M.E.; Brimacombe, K.R.; Chan, S.H.; Rohde, J.M.; Lewis, C.A.; Swier, L.J.; Possemato, R.; Chen, W.W.; Sullivan, L.B.; Fiske, B.P.; et al. A PHGDH inhibitor reveals coordination of serine synthesis and one-carbon unit fate. Nat. Chem. Biol. 2016, 12, 452-458. [CrossRef]

28. Mullarky, E.; Lairson, L.L.; Cantley, L.C.; Lyssiotis, C.A. A novel small-molecule inhibitor of 3-phosphoglycerate dehydrogenase. Mol. Cell. Oncol. 2016, 3, e1164280. [CrossRef]

29. Wang, C.; Wan, X.; Yu, T.; Huang, Z.; Shen, C.; Qi, Q.; Xiang, S.; Chen, X.; Arbely, E.; Ling, Z.Q.; et al. Acetylation stabilizes phosphoglycerate dehydrogenase by disrupting the interaction of E3 Ligase RNF5 to promote breast tumorigenesis. Cell Rep. 2020, 32, 108021. [CrossRef] 
30. Whitmore, L.; Wallace, B.A. Protein secondary structure analyses from circular dichroism spectroscopy: Methods and reference databases. Biopolymers 2008, 89, 392-400. [CrossRef]

31. Caldinelli, L.; Molla, G.; Sacchi, S.; Pilone, M.S.; Pollegioni, L. Relevance of weak flavin binding in human D-amino acid oxidase. Protein Sci. 2009, 18, 801-810. [CrossRef] [PubMed]

32. Caldinelli, L.; Molla, G.; Bracci, L.; Lelli, B.; Pileri, S.; Cappelletti, P.; Sacchi, S.; Pollegioni, L. Effect of ligand binding on human D-amino acid oxidase: Implications for the development of new drugs for schizophrenia treatment. Protein Sci. 2010, 19, 1500-1512. [CrossRef] [PubMed]

33. Mullarky, E.; Xu, J.; Robin, A.D.; Huggins, D.J.; Jennings, A.; Noguchi, N.; Olland, A.; Lakshminarasimhan, D.; Miller, M.; Tomita, D.; et al. Inhibition of 3-phosphoglycerate dehydrogenase (PHGDH) by indole amides abrogates de novo serine synthesis in cancer cells. Bioorg. Med. Chem. Lett. 2019, 29, 2503-2510. [CrossRef]

34. Xu, X.L.; Grant, G.A. Regulation of Mycobacterium tuberculosis D-3-phosphoglycerate dehydrogenase by phosphate-modulated quaternary structure dynamics and a potential role for polyphosphate in enzyme regulation. Biochemistry 2014, 53, 4239-4249. [CrossRef] [PubMed]

35. Grant, G.A. Elucidation of a self-sustaining cycle in Escherichia coli L-serine biosynthesis that results in the conservation of the coenzyme, NAD. Biochemistry 2018, 57, 1798-1806. [CrossRef] [PubMed]

36. Zhao, G.; Winkler, M.E. A novel alpha-ketoglutarate reductase activity of the serA-encoded 3-phosphoglycerate dehydrogenase of Escherichia coli K-12 and its possible implications for human 2-hydroxyglutaric aciduria. J. Bacteriol. 1996, 178, 232-239. [CrossRef] [PubMed]

37. Burton, R.L.; Chen, S.; Xu, X.L.; Grant, G.A. A novel mechanism for substrate inhibition in Mycobacterium tuberculosis D-3phosphoglycerate dehydrogenase. J. Biol. Chem. 2007, 282, 31517-31524. [CrossRef] [PubMed]

38. Mullarky, E.; Lucki, N.C.; Zavareh, R.B.; Anglin, J.L.; Gomes, A.P.; Nicolay, B.N.; Wong, J.C.; Christen, S.; Takahashi, H.; Singh, P.K.; et al. Identification of a small molecule inhibitor of 3-phosphoglycerate dehydrogenase to target serine biosynthesis in cancers. Proc. Natl. Acad. Sci. USA 2016, 113, 1778-1783. [CrossRef]

39. Rosenbloom, J. The mechanism of end product inhibition of serine biosynthesis. 3. Physical and chemical properties of phosphoglycerate dehydrogenase. J. Biol. Chem. 1968, 243, 2099-2107. [CrossRef]

40. Grant, G.A.; Bradshaw, R.A. D-3-Phosphoglycerate dehydrogenase from chicken liver. II. Chemical and physical properties. J. Biol. Chem. 1978, 253, 2727-2731. [CrossRef]

41. Jansen, G.A.; Wanders, R.J. L-2-hydroxyglutarate dehydrogenase: Identification of a novel enzyme activity in rat and human liver. Implications for L-2-hydroxyglutaric acidemia. Biochim. Biophys. Acta 1993, 1225, 53-56. [CrossRef]

42. Donini, S.; Ferrari, M.; Fedeli, C.; Faini, M.; Lamberto, I.; Marletta, A.S.; Mellini, L.; Panini, M.; Percudani, R.; Pollegioni, L.; et al. Recombinant production of eight human cytosolic aminotransferases and assessment of their potential involvement in glyoxylate metabolism. Biochem. J. 2009, 422, 265-272. [CrossRef]

43. Harris, C.M.; Pollegioni, L.; Ghisla, S. pH and kinetic isotope effects in D-amino acid oxidase catalysis. Eur. J. Biochem. 2001, 268, 5504-5520. [CrossRef] [PubMed]

44. Jagannadham, V.; Sanjeev, R. Playing Around with "Kaleidagraph" program for determination of pKa values of mono, di and tri basic acids in a physical-organic chemistry laboratory. Creat. Educ. 2012, 3, 380-382. [CrossRef] 